\title{
EMULSIONS OF WASTE FATS AND OILS FROM METALWORKING PROCESS AS ENVIRONMENTAL POLLUTANTS
}

\author{
UDC 665.7:[621.7.9:669.502.75
}

\section{Miodrag Stanisavljević1, Vesna Lazarević Ana Stojković ${ }^{3}$, Ivan Krstić}

${ }^{1}$ The Academy od Applied Technical Studies, Belgrade, Department - Applied Engineering Sciences, Požarevac, Serbia

${ }^{2}$ Center for Preventive Medical Care in Niš, Military Hospital Niš, Serbia

${ }^{3}$ University of Niš, Faculty of Occupational Safety, Serbia

\begin{abstract}
The exploitation of industrial waste oils and fats, along with the influence of physical, thermal, chemical and biological factors, is the reason for their transformation and formation of waste emulsions that pose a potential risk of environmental pollution. This paper provides an overview of reference technological processes that are considered to be major sources of environmental pollution. In addition, this study presents the qualitative and quantitative characteristics of aqueous emulsions of waste fats and oils from metal processing and thus proposes a system for treatment that would minimize the risk of environmental pollution.
\end{abstract}

Key words: fats and oils, emulsions, metalworking, environmental pollution.

\section{INTRODUCTION}

In recent years, great attention has been paid to the ecological problem of emulsions of waste fats and oils from metal processing industry. Oils and fats can be distinguished by their polarity, biodegradation and physical characteristics [1]. Polar compounds in fats or oils are derivatives of plants and animals found in wastewater during food processing. Non-polar oils and fats are obtained from oil or mineral sources. In general, polar oils and fats are biodegradable, while non-polar ones are considered bio resistant [2].

The main sources of environmental pollution by emulsions of waste fats and oils are steel production and metal processing. Industrialized countries, such as the United Kingdom, Italy and Germany, produce large quantities of wastewater containing emulsified and free

Received June 3, 2020 / Accepted October 12, 2020

Corresponding author: Ana Stojković

University of Niš, Faculty of Occupational Safety in Niš, Serbia, Čarnojevića 10a, 18000 Niš, Serbia

E-mail: ana.stojkovic@znrfak.ni.ac.rs 
oils [3]. Wastewater from hot rolling mills contains primarily lubricants and agents used under hydraulic pressure. In cold rolling mills, steel rods are usually coated with oil prior to rolling in order to prevent corrosion. During rolling, oil-in-water emulsions sprays are used as coolants. Once the molding is finished, the steel is flushed out to remove oil. Water for rinsing and cooling from rolling mills by a cold process can have an oil content of several thousand $\mathrm{mg} / \mathrm{dm}^{3}$, of which $25 \%$ or more can be emulsified, and therefore, difficult to separate from wastewater. According to the report, oil emulsions from the rolling mill spill by the hot process rarely exceed $20 \mathrm{mg} / \mathrm{dm}^{3}$ [4].

In metal processing, coolants and lubricants are used in various kinds of machines and tools, such as lathes, milling machines, grinders, drills and others. During exploitation, machine coolants and lubricants are subjected to physical, chemical and thermal transformations that change their composition [5], [6]. A phenomenon that is constantly present during mechanical metal processing, and appears between the surface of the tool and the object being processed, is known as friction. Friction is accompanied by heat which adversely affects the cutting tool, which is the reason why coolants and lubricants are used. They can be classified into four groups:

- cutting and deformation oils (mineral, fatty, oil blends),

- synthetic agents (containing water and little or no mineral oils),

- oil emulsions (dispersions of two mutually insoluble liquids),

- gaseous agents (compressed air, carbon dioxide, argon, nitrogen).

Coolants and lubricants are the strongest additive oils (they have up to $25 \%$ of oil added to the concentrate and up to $35 \%$ of additives). Additives (polar, anti-corrosive, anti-wear, emulsifiers, anti-foaming agents, antioxidants, etc.) are used to achievecharacteristics that oils do not have or to enhance the effects of oils [7].

However, the above-mentioned additives are a huge environmental problem because they consist of fatty acids, esters, ethers, amines, amides, aldehydes, phosphorus and chlorine compounds, sulfates, phosphates and many other toxic compounds [8].
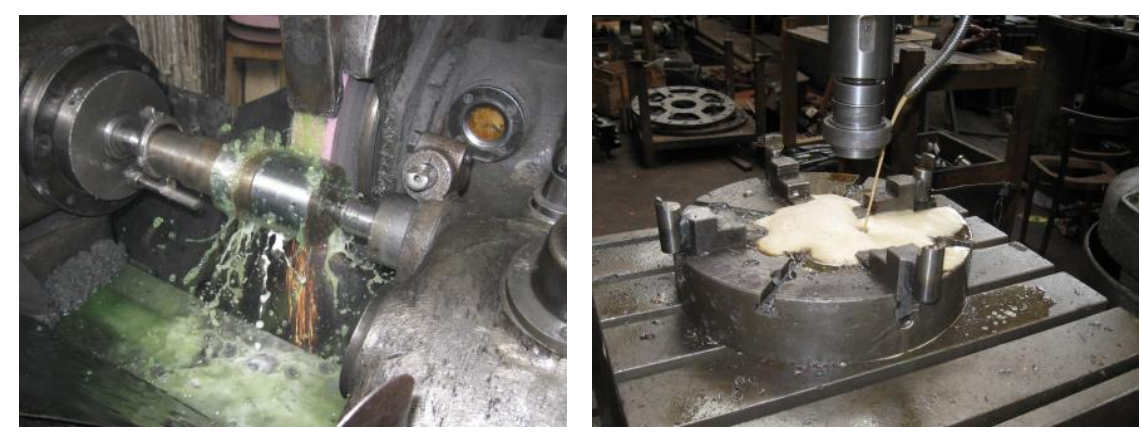

Fig. 1 Cooling emulsions

During their application, coolants and lubricants are subjected to physical, chemical and thermal actions. Under the influence of these factors, their composition changes as well as their physical and chemical characteristics. The changes occur due to decomposition, oxidation, infiltration of various impurities (sawdust, oil emulsions, dust, etc.) and various types of microorganisms (bacteria, fungi, mold). 
Numerous studies indicate that the used agents pose a great danger to human health [9] and the environment $[10,11]$. It has been proven that a single litre of oil can contaminate a million litres of water or that a single ton of waste cooling agents and lubricants pollutes the river water like the wastewater in a city with 40,000 inhabitants; therefore, in case the agents used reach wells and drinking water sources, the consequences can be catastrophic. It is also dangerous to discharge them into sewers and sewage canals because degraded emulsions leave oil spills on the water surface. Oil spills can seriously affect the supply of oxygen to marine flora and fauna because secreted mineral oils could stick to the respiratory organs of living beings, and insect legs and wings [10, 12].

All lubricants, especially the used ones, change the physical and chemical properties of soil and make it infertile over a long period. It has also been proven that the bacteriological decomposition of mineral oil in the soil is long-lasting, so it can contaminate groundwater over a longer period [13].

The aim of this paper is to select the optimal solution for the treatment of waste aqueous emulsions of fats and oils based on qualitative-quantitative characteristics.

\section{EXPERIMENTAL}

Water emulsions of waste fats and oils appear across various industry sectors, such as the production and processing of metals, food production, oil refineries, etc. Table 1 provides an overview of the sources of waste aqueous emulsions of fats and oils, together with their typical concentration values.

Table 1 The concentration of oils and fats in industrial wastewater [14]

\begin{tabular}{lc}
\hline Industrial source & $\begin{array}{c}\text { Oil concentration } \\
{\left[\mathrm{mg} / \mathrm{dm}^{3}\right]}\end{array}$ \\
\hline Metal finishing & $100-5.000$ \\
Oil refinery & $10-3.200$ \\
Steel rolling mill & 7.200 \\
Production of steel wire & 716 \\
Aluminum rolling mill & $500-50.000$ \\
Food industry & 3.830 \\
Fish processing & $520-13.700$ \\
Edible oil refining & $4.000-6.000$ \\
Waste from oil wells & $7-1.300$ \\
Paint manufacturing & 1.900 \\
Aircraft maintenance & $500-1.200$ \\
Maintenance of transport vehicles & 490 \\
Textile industry - Spinning mill & $2.300-8.160$ \\
Tawing (tanning leather) & 40.200 \\
Tire manufacturing & $38-298$ \\
Glass production & $10-25$ \\
\hline
\end{tabular}

It should be emphasized that the concentration of oil and fat in wastewater is not always an indicator of the pollution level, as in the case of periodic discharge or dilution with wastewater. 
The physical appearance of the aqueous emulsion may indicate various problems, such as: the appearance of a layer of free oil on the surface of the emulsion, a change in the appearance of the aqueous emulsion from semi-transparent to milky or the appearance of gray to black colour due to microbial growth.

The appearance of the emulsion is also affected by the size of the dispersed particles and the way they are distributed.

The density of aqueous emulsions of mineral oils at normal temperatures is similar to the density of water.

The metalworking agent may contain acids or bases, and these compounds may be formed by degradation of individual components during use. The alkalinity may increase during the aging of the metalworking agent, because it is unlikely that the alkaline components will be separated by secondary oil, carbonates from water or other contaminants. A sudden increase in alkalinity is a sign of contamination, while a decrease in alkalinity signals the instability of the metalworking agent $[15,16]$.

Mineral oils, due to their composition, have the ability to react with dichromate in an acidic environment, which means that they have certain chemical oxygen consumption. Regardless of the type, the chemical consumption of oxygen is directly proportional to the concentration of mineral oil and is acknowledged as a measure of the concentration of mineral oil in wastewater emulsions.

Qualitative characteristics of mechanically treated wastewater are gray colour which arises from emulsified oil, floating oil, a significant amount of emulsified organic matter (COD), low biodegradability of organic matter $\left(20^{\circ} \mathrm{C} \mathrm{BOD}_{5}\right)$ and oils and fats.

Table 2 shows the physical and chemical characteristics of wastewater from a smaller mechanical treatment plant with an average water consumption of 3,5 1/h.

Table 2 Physical-chemical characteristics of wastewater from mechanical metal processing

\begin{tabular}{lcc}
\hline Indicators & Collective wastewater & Inlet water \\
\hline Temperature, ${ }^{\circ} \mathrm{C}$ & $30-50$ & $12-20$ \\
Colour & grey & without color \\
Floating substances & oils & without \\
Suspended matters, mg/l & $100-300$ & $20-30$ \\
Dry residue, mg/l & $300-1150$ & $40-60$ \\
$\mathrm{COD}, \mathrm{mg} \mathrm{O}_{2} / \mathrm{l}$ & $1500-2400$ & $6-11$ \\
$20^{\circ} \mathrm{CBOD}, \mathrm{mg} \mathrm{O} / \mathrm{l}$ & $180-288$ & $1,5-3$ \\
Oils and fats, mg/l & $6,3-15,8$ & 0,00 \\
Iron, $\mathrm{mg} / \mathrm{l}$ & $0,03-0,11$ & 0,00 \\
Chromium $(\mathrm{VI}), \mathrm{mg} / \mathrm{l}$ & 0,00 & 0,00 \\
\hline
\end{tabular}

The most common receiver of wastewater emulsions is a city sewage system. The criterion that is applied for the discharge of wastewater into this receiver is the Rulebook on technical and sanitary conditions for wastewater discharge to the city sewer system. Comparing the maximum allowable concentrations (MAC) from the above-mentioned Rulebook with the values given in Table 1, we have noticed a significantly increased concentration of emulsified organic matter $\left(\mathrm{COD}=1500-2400 \mathrm{mgO}_{2} / \mathrm{l} ; \mathrm{MAC} \mathrm{COD}=450\right.$ $\mathrm{mgO}_{2} / \mathrm{l}$ ) which should be removed by pre-treatment. The efficiency in terms of COD that should be achieved is in the range between 70 and $81.25 \%$, together with the stabilization of the wastewater temperature. 
Fats and oils prevent the oxygen absorption from the atmosphere into the water, and also prevent the penetration of sunlight which is necessary for photosynthesis. The reduction of oxygen in surface waters has great consequences on the aquatic ecosystem and natural balance. In addition, alkylbenzenesulfonates and mineral oils and fats also have a primary toxicological effect on the aquatic ecosystem at concentrations greater than $1 \mathrm{mg} / \mathrm{dm}^{3}$. These are organic substances that are considered poorly biodegradable or nonbiodegradable.

Based on the measured values of fat and oil concentration, Figure 2 shows a graphical overview of the relationship between the mean values of the organic loading concentration and the measurement year.

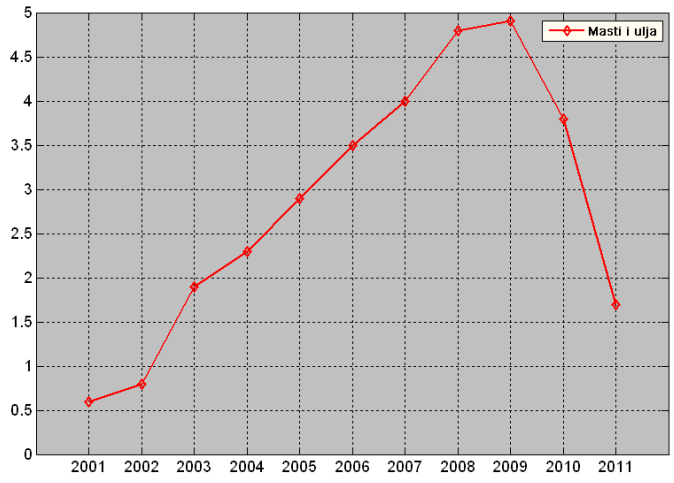

Fig. 2 The relationship between the mean values of the organic loading concentration and the measurement year

The values of the concentration of wastewater fats and oils in the observed period are within the permitted range; however, the cumulative effect of other pollutants increases the organic load, which has a negative impact on the quality of the environment.

\section{RESULTS AND DiSCUSSION}

The treatment of aqueous emulsions of waste fats and oils can be performed in plants that are capable of sustaining very efficient and regenerative processes, such as ultrafiltration, as it has been stated in the research by Tomaszevska et al. [17] who used an integrated process of ultrafiltration and reverse osmosis to remove all oil, as well as more than $90 \%$ of all tested cations $\left(\mathrm{Na}^{+}, \mathrm{K}^{+}, \mathrm{Mg}^{2+}, \mathrm{Ca}^{2+}, \mathrm{Zn}^{2+}, \mathrm{Mn}^{2+,} \mathrm{Al}^{3+}, \mathrm{Li}^{+}\right)$. Despite the stability of the emulsion, ultrafiltration is a method for separation of oil in oil-water emulsion with an efficiency of up to $99 \%$, with the possibility of reusing oil (regeneration) and water (recirculation). The use of ultrafiltration in the technology of wastewater treatment of mechanical metal processing has a double effect - the protection of surface water and the reuse of oil from emulsions in the process of cooling cutting tools.

Figure 3 shows the technological scheme of the plant for wastewater treatment from mechanical treatment of metals, with intensive physical and chemical treatment. 


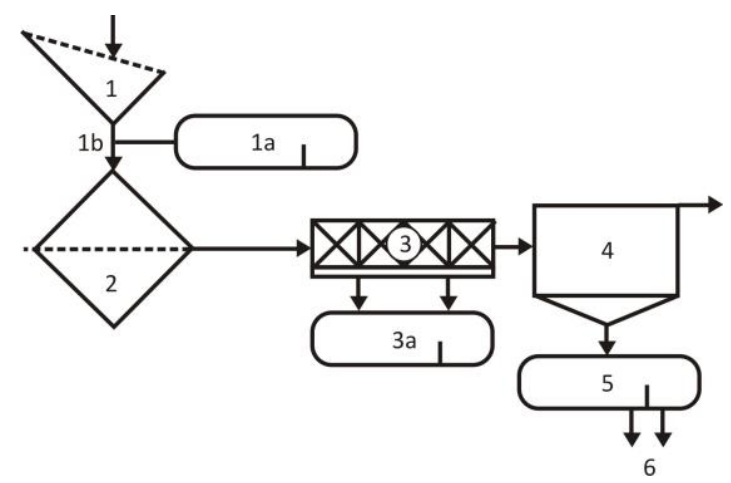

Fig. 3 Technological scheme of the plant for wastewater treatment from mechanical metal processing, with intensive physicochemical treatment

\section{Waterline:}

influent - untreated wastewater from mechanical metal processing;

1 - a sieve used to remove larger metal particles;

1a - a container for metal particles removed from the sieve, recycled with other metal waste (this type of waste does not dissolve in water, so it is harmless to the environment);

$1 \mathrm{~b}$ - a flow meter;

2 - an equalization basin used to reduce wastewater temperature and equalize the flow and concentration of hazardous substances;

3 - a flotation device where the coagulation-flocculation process is performed (intensive physical and chemical purification);

$3 \mathrm{a}-\mathrm{a}$ container for oil removal by flotation and coagulation and its stabilization by solidification with quicklime $(\mathrm{CaO})$;

4 - cylindrical-conical primary precipitator;

effluent - treated wastewater from metal processing that is discharged into the city sewer.

Sludge line:

5 - a collecting tank for coagulated sludge which is stabilized by solidification with quicklime;

6 - disposal of solidified sludge at the municipal solid waste landfill.

Intensive physical and chemical wastewater treatment is a more cost-effective investment solution. The main processes of intensive physical-chemical treatment are coagulation, flocculation, flotation and deposition. The efficiency of plants with intensive physical-chemical treatment based on COD is between 90 and 95\%, where the agent and the dose of coagulants and flocculants are confirmed in the laboratory. Also, the technological parameters of flotation are determined in the laboratory: the mass of air to remove the destabilized emulsion, bubble size, the speed of lifting the air bubbles, etc.

Figure 4 shows the technological scheme of the plant for wastewater treatment from metal processing using the ultrafiltration process. 


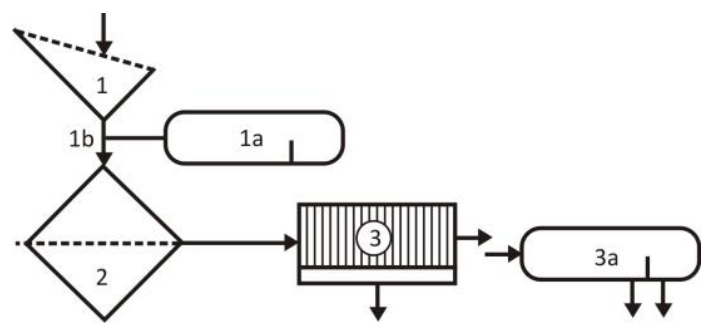

Fig. 4 Technological scheme of the plant for wastewater treatment from metal processing using ultrafiltration

\section{Waterline:}

influent - untreated wastewater from mechanical metal processing;

1 - a sieve used to remove larger metal particles;

1a - a container for metal particles removed from the sieve, recycled with other metal waste (this type of waste does not dissolve in water, so it is harmless to the environment);

$1 \mathrm{~b}$ - a flow meter;

2 - a container for metal particles removed from the sieve, recycled with other metal waste (this type of waste does not dissolve in water, so it is harmless to the environment);

3 - ultrafiltration, hollow fiber modules; effluent - treated wastewater from metal processing that is discharged into the city sewer.

\section{Sludge line:}

$3 \mathrm{a}-$ an oil tank separated by ultrafiltration, which is returned to the cooling process of the cutting tools.

\section{CONCLUSION}

Based on the qualitative and quantitative characteristics of aqueous emulsions of waste fats and oils, this paper highlights the risk of environmental pollution. Besides, some design solutions involving physical-chemical treatment and ultrafiltration have been given in order to provide the options for efficient treatment of aqueous emulsions of waste fats and oils. The procedure of physical-chemical treatment produces coagulation sludge which is considered as a secondary pollutant, while ultrafiltration process meets the requirements of clean technologies. For this reason, preference should be given to the use of unconventional treatment systems, with the aim to minimize the risk of environmental pollution.

Acknowledgement: This research was financially supported by the Ministry of Education, Science and Technological Development of the Republic of Serbia. 


\section{REFERENCES}

1. Lan WU, Gang GE and Jinbao WAN (2009). Biodegradation of oil wastewater by free and immobilized Yarrowia lipolytica W29. Journal of Environmental Sciences 21(2):237-242.

2. Travis MJ, Weisbrod N and Gross A (2008). Accumulation of oil and grease in soils irrigated with greywater and their potential role in soil water repellency. Science of the Total Environment 394:68-74

3. Busca GTM, Doctoral Dissertation (2004). Treatment of Semi-Synthetic Metalworking Fluids: Membrane Filtration and Bioremediation. University of Nottingham UK

4. Lazarević V (2004). Prečišćavanje otpadne vodene emulzije iz procesa obrade metala. Magistarski rad. Univerzitet u Nišu. Tehnološki fakultet u Leskovcu

5. Schulz J, Brinksmeier E and Meyer D (2013). On the Interactions of Additives in Metalworking Fluids with Metal Surfaces. Lubricants 1:75-94. doi:10.3390/lubricants1040075

6. Brinksmeier E, Meyer D, Huesmann-Cordes AG, Herrmann C (2015). Metalworking fluids-Mechanisms and performance. CIRP Annals-Manufacturing Technology 64 (2):605-628.

7. Portela JR, Sanchez-Oneto J, Garcia-Jarana MB, Nebot Sanz E, Martinez de la Ossa EJ (2009). Comparison of different hydrothermal processes for the elimination of cutting fluid wastes. Chem Eng Transact 17:245-250.

8. Schwarz M, Miroslav D, Hnilica R and Veverkova D (2015). Environmental and Health Aspects of Metalworking Fluid Use. Pol. J. Environ. Stud. 24 (1):37-45

9. Leppert T. (2011). Effect of cooling and lubrication conditions on surface topography and turning process of C45 steel. International Journal of Machine Tools and Manufacture 51:120-126. DOI:10.1016/j.ijmachtools.2010.11.001.

10. Stanisaljević, P.M., Technologies of wastewater treatment and industrial hazardous waste, Technical College of Vocational Studies Požarevac, 2010.

11. Islam MS, Saiful M, Hossain M, Sikder M, Morshed M and Hossain M (2013). Acute toxicity of the mixtures of grease and engine wash oil on fish, pangasius sutch, under laboratory condition. International Journal Life Science, Biotechnology and Pharmacology Research, 2(1):306-317

12. Wake $H$ (2005). Oil refineries: A review of their ecological impact on the aquatic environment. Estuarine, Coastal and Shelf Science 62 (1-2):131-140

13. Udonne JD, Onwuma HD (2014). A study of the effect of waste lubricating on the physical/chemical properties of soil and the possible remedies. J Petrol Gas Eng 5(1):9-14 (Academic Journals). http://www.academicjournals.org/JPGE.

14. [14] Patterson J. W. (1985): Industrial Wastewater Treatment Technology, 2nd Edition, Butterwoth Publishers, Boston, pp.273-297.

15. Eldeen S and Hegazi F (2015). Conversion of used Oil into Lubricating Grease and Characteristics Evaluation. International Journal of Science and Research 4 (4): 1894-1898.

16. Benito, J.M., Cambiella, A., Lobo, A., Gutierrez, G., Coca, J., Pazos, C., Formulation, characterization and treatment of metalworking oil-in-water emulsions, Clean Techn Environ Policy, Berlin, 2010, pp. 31.

17. Tomaszewska M, Orecki A and Karakulski K (2005). Treatment of bilge water using a combination of ultrafiltration and reverse osmosis. Desalination and the Environment 185(1-3): 203-212

\section{OTPADNE EMULZIJE MASTI I ULJA IZ TEHNOLOŠKOG PROCESA OBRADE METALA KAO ZAGAĐUJUĆE MATERIJE ŽIVOTNE SREDINE}

Eksploatacijom industrijskih masti $i$ ulja, usled delovanja fizičkih, termičkih, hemijskih $i$ bioloških faktora, dolazi do njihove transformacije i stvaranja otpadnih emulzija koje predstavljaju potencijalni rizik zagađenja životne sredine. U radu su dati referentni tehnološki procesi koji predstavljaju izvore ovih zagađujućih materija, a zatim je dat prikaz kvalitativno-kvantitativnih karakteristika otpadnih vodenih emulzija masti $i$ ulja iz procesa obrade metala, kao i predlog sistema prečišćavanja, kojim se rizik zagađenja životne sredine svodi na minimum.

Ključne reči: masti i ulja, emulzija, obrada metala, zagađenje životne sredine. 